U. S. DEPARTMENT OF COMMERCE BUREAU OF STANDARDS

\title{
MEN'S PAJAMAS
}

(Made from Woven Fabrics)

COMMERCIAL STANDARD CS15-29

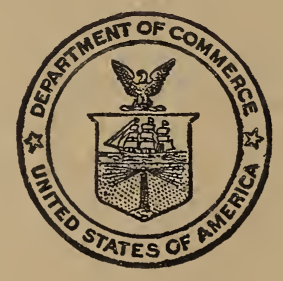

ELIMINATION OF WASTE

Through

SIMPLIFIED COMMERCIAL PRACTICE 
Below are described some of the series of publications of the Department of Commerce which deal with various phases of waste elimination.

\section{Simplified Practice Recommendations.}

These present in detail the development of programs to eliminate unnecessary variety in sizes, dimensions, styles, and types of over 100 commodities. They also contain lists of associations and individuals who have indicated their intention to adhere to the recommendations. These simplified schedules, as formulated and approved by the industries, are indorsed by the Department of Commerce.

\section{Commercial Standards.}

These are developed by various industries under a procedure similar to that of simplified practice recommendations. They are, however, primarily concerned with considerations of grade, quality, and such other characteristics as are outside the scope of dimensional simplification.

\section{American Marine Standards.}

These are promulgated by the American Marine Standards Committee, which is controlled by the marine industry and administered as a unit of the division of simplified practice. Their object is to promote economy in construction, equipment, maintenance, and operation of ships. In general, they provide for simplification and improvement of design, interchangeability of parts, and minimum requisites of quality for efficient and safe operation.

Lists of the publications in each of the above series can be obtained by applying to the Bureau of Standards, Washington, D. C. 


\section{U. S. DEPARTMENT OF COMMERCE}

R. P. LAMONT, Secretary

BUREAU OF STANDARDS

GEORGE K. BURGESS, Director

\section{MEN'S PAJAMAS}

(Made from Woven Fabrics)

\section{COMMERCIAL STANDARD CSI5-29}

[ISSUED MAY 27, 1930]

Effective Date For New Production, January 30, 1930

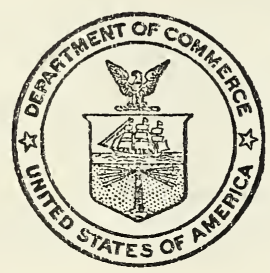

UNITED STATES

GOVERNMENT PRINTING OFFICE

WASHINGTON : 1930 


\section{CONTENTS}

Áceeptors

Commercial standard

General conference.

Effective date

Standing committee-

Certification plan

derds

Commercial standards service............

Organization and duties of standing committee.

Your cooperation

Acceptance of commercial standard

To the acceptor

Request for commercial standards

d.-

List of commercial standards 


\section{COMMERCIAL STANDARD CS15-29}

\section{ACCEPTORS}

\section{ASSOCIATIONS}

American Home Economics Association, Washington, D. C.

Associated Dry Goods Corporation, New York, N. Y.

General Federation of Women's Clubs, Washington, D. C.

National Association of Retail Clothiers and Furnishers, Chicago, Ill.

\section{FIRMS}

Carlson Garment Co., Los Angeles, Calif.

Colorado Agricultural College, Fort Collins, Colo.

Faultless Manufacturing Co., The, Baltimore, Md.

Goldheim's, Washington, D. C.

Greenebaum Weil \& Michels, San Francisco, Calif.

Howarth-Snyder Co., New York, N. Y.

Knothe Bros. Co. (Inc.), New York, N. Y.

Reis \& Co., Robert, New York, N. Y.

Rhodes Bros. (Inc.), Tacoma, Wash.

Rowell \& Son (Inc.), W. P., Worcester, Mass.

$108038^{\circ}-30$
FIRMS-continued

Sears, Roebuck \& Co., Chicago, Ill.

Simons Manufacturing Co., Ernest, New York, N. Y.

Steiner \& Son (Inc.), Asbury Park, N. J.

Valco Manufacturing Co. (Inc.), New York, N. Y.

Varsity Underwear Co. (Inc.), Baltimore, Md.

Wachusett Shirt Co., Leominster, Mass.

Wolf \& Sons (Inc.), H., Cincinnati, Ohio.

Woodman Co., F. T., Cambridge, Mass.

Woodward \& Lothrop, Washington, D. C.

\section{GOVERNMENT}

Federal Specifications Board, Washington, D. C.

Government of the District of Columbia, Washington, D. C.

National Home for Disabled Volunteer Soldiers, Dayton, Ohio.

Treasury Department, Washington,D.C. Veterans' Bureau, Washington, D. C. 



\section{MEN'S PAJAMAS}

(Made from Woven Fabrics)

\section{COMMERCIAL STANDARD CS15-29}

On May 3, 1929, a general conference of manufacturers, distributors, and users adopted a commercial standard for men's pajamas. The industry has since accepted and approved for promulgation by the Department of Commerce the measurements shown herein.

This standard is effective for new production frcm January 30, 1930.

Promulgation recommended.

Promulgated.

$$
\text { I. J. FaIrchild, }
$$
Chief, Division of Trade Standards.

APPROVED.

George K. Burgess, Director, Bureau of Standards.

R. P. Lamont, Secretary of Commerce. 


\section{COMMERCIAL STANDARD CS15-29}

The measurements given herein are recommended as standard minimum measurements for finished garments made from woven fabrics.

For method of measuring, see pages 2-4, also Figures 1 and 2.

\section{TABLE 1.-Pajama coats and trousers}

[Standard minimum measurements]

COATS

\begin{tabular}{|c|c|c|c|c|}
\hline \multirow{2}{*}{ Key points } & \multicolumn{4}{|c|}{ Measurements, size- } \\
\hline & A & B & C & $\mathrm{D}$ \\
\hline $\begin{array}{l}\text { Length } \\
\text { Chest } \\
\text { Armhole } \\
\text { Sleeve length } \\
\text { Sleeve bottom } \\
\text { Bottom of coat. }\end{array}$ & $\begin{array}{r}\text { Inches } \\
30 \\
43 \\
20 \\
32 \\
12 \\
43\end{array}$ & $\begin{array}{l}\text { Inches } \\
301 / 2 \\
47 \\
211 / 2 \\
32 \\
121 / 2 \\
47\end{array}$ & \begin{tabular}{c|} 
Inches \\
$301 / 2$ \\
50 \\
22 \\
$331 / 2$ \\
13 \\
50
\end{tabular} & $\begin{array}{l}\text { Inches } \\
31 \\
54 \\
221 / 2 \\
34 \\
131 / 2 \\
54\end{array}$ \\
\hline
\end{tabular}

TROUSERS

\begin{tabular}{|c|c|c|c|c|}
\hline $\begin{array}{l}\text { Waist. } \\
\text { Seat, } \\
\text { Thigh, } \\
\text { Rise, front } \\
\text { Rise, back }\end{array}$ & $\begin{array}{l}39 \\
50 \\
27 \\
141 / 2 \\
151 / 2\end{array}$ & $\begin{array}{l}42 \\
521 / 2 \\
28 \\
15 \\
16\end{array}$ & $\begin{array}{l}45 \\
56 \\
29 \\
16 \\
18\end{array}$ & $\begin{array}{l}49 \\
61 \\
32 \\
17 \\
181 / 2\end{array}$ \\
\hline $\begin{array}{l}\text { Outseam } \\
\text { Inseam } \\
\text { Knee. } \\
\text { Bottoms. }\end{array}$ & $\begin{array}{l}42 \\
281 / 2 \\
20 \\
17\end{array}$ & $\begin{array}{l}43 \\
29 \\
21 \\
171 / 2\end{array}$ & $\begin{array}{l}44 \\
30 \\
23 \\
181 / 2\end{array}$ & $\begin{array}{l}45 \\
30 \\
24 \\
20\end{array}$ \\
\hline
\end{tabular}

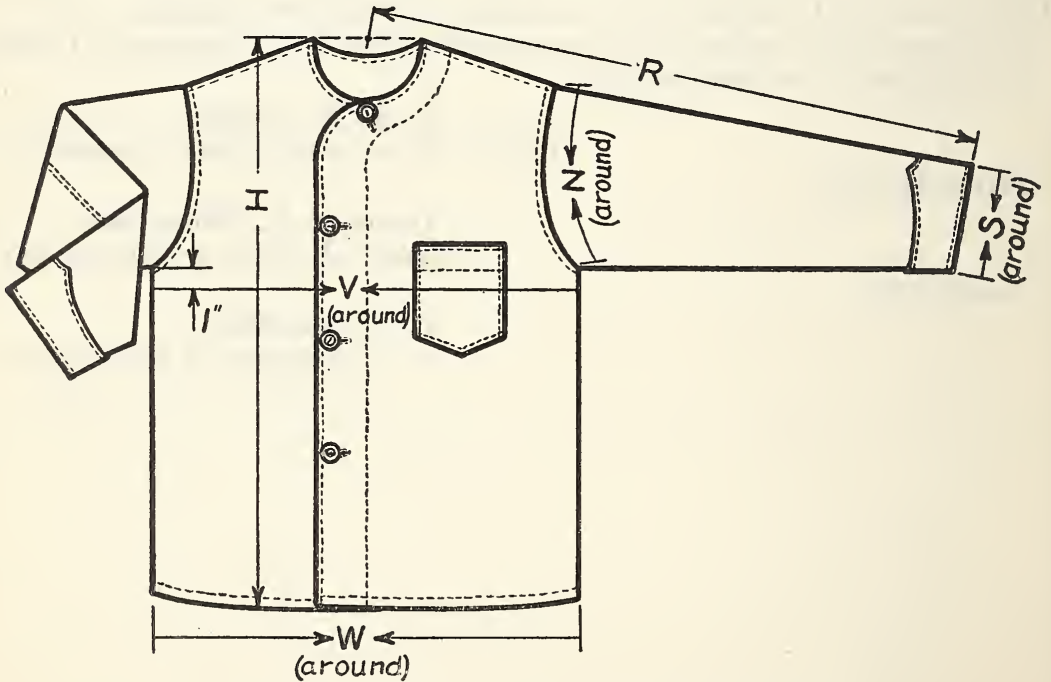

FIGURE 1.-Method of measuring pajama coat

\section{METHOD OF MEASURING}

PAJAMA COAT (FINISHED)

Length.-The measurement is taken from the point where the shoulder seam joins the collar band, both down the front and back to the bottom of the garment. ( $H$, fig. 1.) 
Chest.-Taken 1 inch below the bottom of the armholes. Measure completely around the garment when closed with buttons, loops, or snappers. ( $V$, fig. 1.)

Armhole.-Taken at the outer edge of the armhole seam. Measure from the shoulder seam completely around the armhole. ( $N$, fig. 1.)

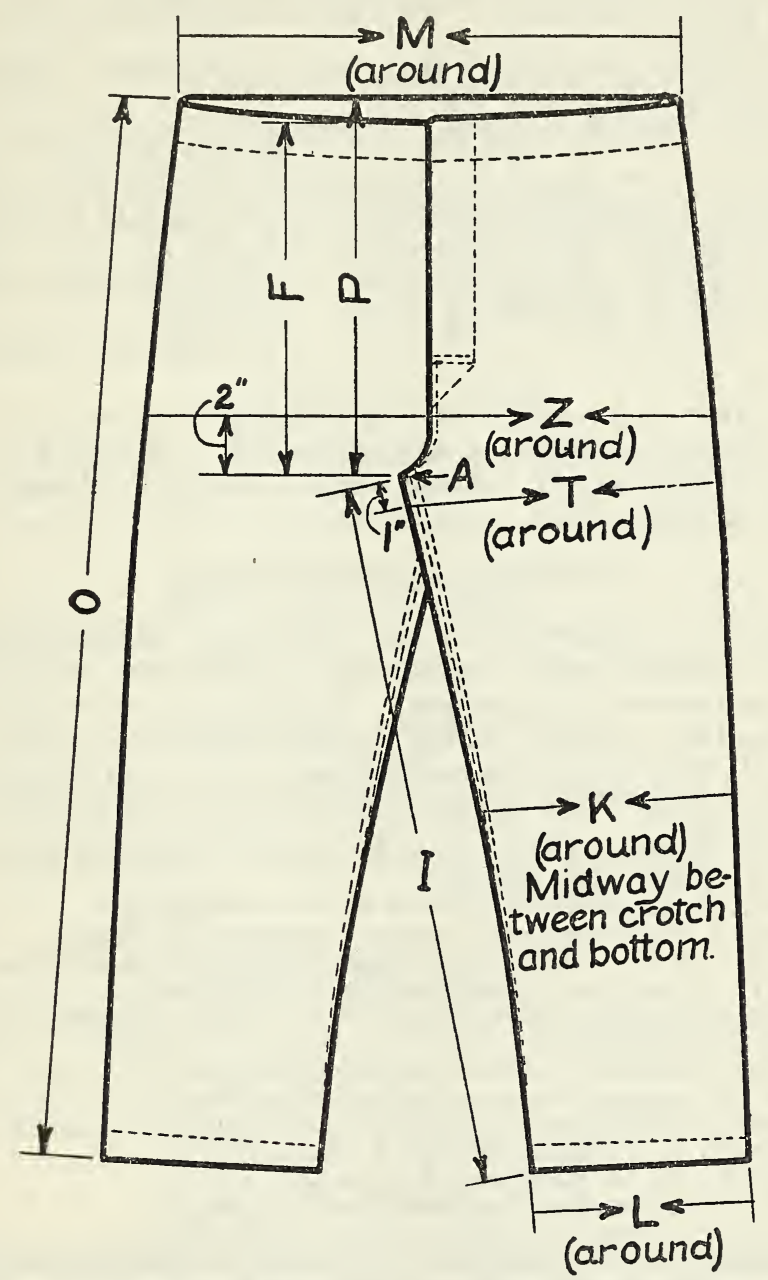

FigdRE 2.-Method of measuring pajama trousers

Sleeve length.-Taken from the center of the top of yoke, when straight cut, across the top of the shoulder to the end of the sleeve at the bottom. Where the top of yoke is circular begin at the center of a straight line drawn between the two top points. ( $R$, fig. 1.)

Sleeve bottom.-Taken at the bottom edge of the sleeve. Measure the circumference of the opening. (S, fig. 1.)

Bottom of coat.-Taken at the bottom of the garment. Measure completely around the garment when closed with buttons, loops, or snappers. ( $W$, fig. 1.) 


\section{PAJAMA TROUSERS (FINISHED)}

Note.-The crotch is the point where the two inseams join the seat seam. (A, fig. 2.)

Waist.-This measurement is taken completely around top edge of garment when the garment is buttoned. ( $M$, fig. 2)

Seat.-Taken 2 inches above the crotch completely around the garment. ( $Z$, fig. 2.)

Thigh.-Taken on the leg 1 inch below the crotcn; measure completely around the leg. ( $T$, fig. 2.)

Rise (front).-Taken from the crotch up the front of the garment at the center, to the top of the waistband. (F, fig. 2.)

Rise (back).-Taken from the crotch up the back of the garment at the center to the top of the waistband. ( $P$, fig. 2.)

Outseam.-Taken on the outseam of the leg from the top of the waistband down to the bottom of leg. (O, fig. 2.)

Inseam.-Taken from the crotch down the inside of the leg to the bottom. ( $I$, fig. 2.)

Knee.-Taken at a point on the leg midway between the crotch and bottom. Measure completely around the leg. ( $K$, fig. 2.)

Botioms.- Taken at the bottom edge of the leg. Measure the circumference of the opening. (L, fig. 2.)

\section{GENERAL CONFERENCE}

Agreeable to a request from the Nightwear Manfacturers Division of the International Association of Garment Manufacturers a general conference of producers, distributors, users, and general interests was held on May 3, 1929, at the Commerce Building, Washington, D. C., to consider the establishment of a commercial standard for men's pajamas. The following individuals were present:

Allison, A. F., secretary, International Association of Garment Manufacturers. Atchison, J. C., Daily News Record.

BaChRACH, SidNey L., treasurer, Liberty Manufacturing Co.

BenNer, OTto J., superintendent, Varsity Underwear Co. (Inc.).

Downing, William F., merchandise manager, Woodward \& Lothrop.

Foos, Irvin D., correspondent, National Retail Clothier.

Gibson, R. S., section chief, Group D., division of supply, Treasury Department.

Goldheim, I. L., Goldheims.

Hardie, Harry, president, Faultless Manufacturing Co.

HARRison, W. M., general manager, Steiner \& Son (Inc.).

Holden, JAMES, chief pharmacist, United States Navy.

HorNer, HoraCe K., president, Horace K. Horner (Inc.).

LeimberG, W. F., buyer, Woodward \& Lothrop.

Polmer, S. C., vice president, Faultless Manufacturing Co.

Schaffer, Charles, chief pharmacist, United States Navy.

Shipley, Frederic B., vice president, Ernest Simons Manufacturing Co.

Sochel, George Y., secretary, Horace IK. Horner (Inc.).

Steine R, C. S., secretary and treasurer, Steiner \& Son (Inc.).

Stick, Nathaniel I., reporting stenographer, Convention Reporting Co.

Valentine, Irving, treasurer, Valco Manufacturing Co. (Inc.).

Voeth, Maj. Robert W., vice chairman, Federal Specifications Board.

WeIL, L. H., president, Varsity Underwear Co.

Young, Harold R., National Retail Dry Goods Association.

Department of Commerce:

DeGolia, Darwin, wearing apparel specialist, United States Department of Commerce.

FaIRChild, I. J., chief, division of trade standards, Bureau of Standards.

PICKARD, E. T., chief, textile division, Bureau of Foreign and Domestic Commerce.

WoFPORD, J. B., survey of current business, United States Census Bureau. 
The meeting was conducted by I. J. Fairchild, who outlined the procedure for the establishment of commercial standards.

A. F. Allison reviewed the development of the proposed commercial standard and the purposes of the manufacturers in attempting such work. He was followed by Mr. Steiner, who stated that the main purpose is to eliminate the production of undersized garments as well as to avoid complaint on this score. He indicated that the manufacturers desire a minimum size standard which will be applicable throughout the United States and which will be indicated by a label or tag as a means of informing distributors and consumers of complete compliance with the standard.

Following discussion, with particular reference to the question of shrinkage, the proposed standard was modified in certain minor particulars, and upon motion by Mr. Steiner, seconded by Mr. Goldheim, it was voted to adopt the proposed commercial standard as revised by the conference.

\section{EFFECTIVE DATE}

It was the consensus of opinion that the effective date for new production should be not later than October 1, 1929, and that no date should be set for final clearance of existing stocks. In order to permit the development of a satisfactory guarantee labeling system, the industry purposely delayed filing acceptances. Accordingly, success of the project was not announced until January 30,1930 , on which date the commercial standard was made effective for new production.

\section{STANDING COMMITTEE}

The following standing committee was appointed by unanimous consent to consider annually any comments or suggestions as to changes in the standard in order that it may be kept in accord with the desires of the industry and the advance in the art:

C. S. StEiner, Steiner \& Son, chairman.

S. E. GoldsteIN, Valco Manufacturing Co. (Inc.).

F. B. Shipley, Ernest Simons Manufacturing Co.

A. F. ALLISON, secretary, International Garment Manufacturers Ȧssociation.

W. F. Leimberg, National Association of Retail Clothiers and Furnishers, also National Retail Dry Goods Association.

Mrs. Marion Farrington, General Federation of Women's Clubs.

Miss Bess Viemont, American Home Economics Association.

\section{CERTIFICATION PLAN}

The general conference requested the National Bureau of Standards to apply the certification plan to this commercial standard.

The certification plan as applied by the National Bureau of Standards to commercial standards consists in the compilation and distribution of lists of manufacturers who are willing, when requested to do so, to certify to purchasers that products supplied by them comply with all the requirements and tests set forth in nationally recognized commercial standards. The plan is also applied to selected Federal specifications.

These lists are available on request to individual consumers, consumer groups, companies, and in fact, to any prospective purchasers, for their guidance. 
The benefits now derived from the use of specifications by large consumers are thus made immediately available to the small consumer, with incidental advantage to the larger consumers of convenience in ordering and accepting material with fewer laboratory tests, and of lowering the price by reason of broadening the field of supply. The manufacturer also benefits from the well-known economies accompanying "mass production."

The lists of manufacturers "willing-to-certify" to the quality of certain commodities are made by corresponding with, as nearly as possible, all the manufacturers of that product, and listing only those who signify their willingness to certify to the purchaser, when requested to do so, that the commodities delivered actually comply with the commercial standard.

Obviously, the purchaser making use of the lists of "willing-tocertify" manufacturers, will select therefrom such manufacturers as are known (or assumed) by him to be reliable.

The trend toward the purchase of materials of certified quality from sources shown on such willing-to-certify lists supplies added incentive to standardization on the part of other producers, and thus the benefits of the certification plan will be felt by purchasers either directly or indirectly, whether or not they make use of the plan themselves.

\section{COMMERCIAL STANDARDS SERVICE}

Industry has long sensed the need for a wider application and use of specifications developed and approved by nationally recognized organizations. To assist these bodies and the producers and consumers in securing this result and as a natural outgrow th of the movement toward elimination of waste through simplified practice, the National Bureau of Standards has set up a procedure under which specifications, properly indorsed, may be printed as official publications of the Department of Commerce and promulgated as "commercial standards." This. service parallels that of simplified practice in many respects, and is available only upon request.

Broadly speaking, the aim is to continue the same character of cooperative service in this field that is being rendered in simplification. The division of trade standards is not designed to act as a. standardizing body, nor will it engage in the preparation of specifications. Its service is mainly promotional in character, since its chief mission is to get behind a standard or a specification which any branch of industry may want to promulgate on a nation-wide basis; to determine its eligibility for promulgation; to publish and broadcast it in the event the prerequisites of procedure have been met, including a satisfactory majority acceptance; to facilitate the application of the certification plan for the assurance and convenience of the purchaser; to provide means for periodic audits of adherence; and to cooperate with the Bureau of Foreign and Domestic Commerce in determining the desire of industry relative to translation and promulgation of such specifications as a basis for foreign commerce.

In general, it may be said that a simplification covers types, sizes, and varieties of a commodity which are retained by industry on the basis of demand, whereas a commercial standard establishes definite requirements as to grade, quality, or dimensional tolerances in addition to any limitation of variety desired and accepted by the industry. 
In order to carry on the aims and desires of the industry in the standardization of their product, a standing committee is appointed at the general conference. This committee consists of members. from each division of the industry, namely, producers, distributors, and consumers, and thus reflects the well-balanced viewpoint of all concerned.

The members of the committee receive all suggestions regarding the commercial standard and consider its revision in the event that such action is desirable and mutually beneficial.

If the commercial standard does not warrant revision, it is reaffirmed in its existing form, but if any important changes are found desirable, their adoption is recommended by the committee, whereupon the industry is again solicited for written acceptance of the standard in its revised form.

The committee is in effect a centralizing agency for criticisms and comments regarding the commercial standard and is charged with the responsibility of recommending revisions to keep the standard abreast with current industrial practice.

The proper functioning of the committee requires that, when necessary, its members be willing to attend meetings held at some central place, although in many cases it will be possible to conduct the work by correspondence.

When any deceptions in reference to the commercial standard are reported to the standing committee, it applies moral suasion or such other corrective measures as seem desirable. The Department of Commerce has no "police power" to compel adherence; therefore, it is incumbent upon the standing committee to do all in its power to encourage all divisions of the industry to follow the provisions of the commercial standard and contribute in every way possible to its general adoption and usefulness.

\section{YOUR COOPERATION}

As a producer, distributor, or consumer of some of the commodities. for which commercial standards have already been established, you are in a position to avail yourself of the benefits arising from the use of quality standards and incidentally to add impetus to this method of eliminating waste.

The first step is a declaration in favor of the standard by recording. your intention to adhere, as closely as circumstances will allow, to the standards for those products which you may buy or sell.

The receipt of your signed acceptance will permit the listing of your company in new editions of the commercial standards that you accept.

You will, of course, want to examine any commercial standards before signing a formal acceptance. The National Bureau of Standards will, therefore, furnish a copy of any standard under consideration for acceptance. To facilitate this procedure, a list appears on page 12 that may be checked and mailed to the Division of Trade Standards, Bureau of Standards, Washington, D. C. The publications may also be secured singly or in quantities at a nominal price from the Government Printing Office. Prices will be furnished upon request. 
The acceptance of a commercial standard is an entirely voluntary action, and applies to the production, sale, and use of stock items. It is not meant to interfere with the manufacture or sale of special sizes and types sometimes required.

Trade associations and individual companies often distribute large numbers of the printed standard for the information and guidance of their members or customers. In such cases it is possible to extend the scope and degree of adherence by urging each recipient to send in an acceptance, bearing in mind that the practical value of any standardization is measured by the observance it receives.

An acceptance form for the commercial standard herein covered is included on page 9. 


\section{ACCEPTANCE OF COMMERCIAL STANDARD}

Please Sign and Return this Sheet to Division of Trade Standards, Bureau of Standards, Washington, D. C.

Date

Division of Trade Standards,

Bureau of Standards,

Washington, D. C.

Gentlemen: We, the undersigned, do hereby accept the original draft of the commercial standard as our standard practice in the

Production ${ }^{1}$ Distribution $^{1}$
Use $^{1}$ of men's pajamas (made from woven fabrics),

beginning and will use our best effort in securing its general adoption.

To permit intelligent review of the effectiveness of the commercial standard every year by an accredited committee of all interests, working in cooperation with the Department of Commerce, we plan to supply all data, upon request, which may be necessary for the development of constructive revisions. It is understood that any suggested modifications will be submitted as soon as formulated, and shall not be promulgated until accepted in form similar to this recommendation.

Signed

(Kindly typewrite or print the following lines)

Title

Company

Street address

City and State

We are members of the following associations or other organizations interested in the production, sale, or use of men's pajamas (made from woven fabrics).

1 Please designate which group you represent by drawing lines through the other two. In the case of related interests, trade papers, colleges, etc., desiring to record their general approval, the words "in principle" should be added after the signature. 


\section{TO THE ACCEPTOR}

In signing the acceptance blank, please bear the following points clearly in mind:

1. Adherence.-The Department of Commerce has no regulatory powers to enforce adherence to the commercial standards. Instead, this waste-elimination program is based on voluntary cooperation and self-government in industry. To make' this specific standardization operate as a satisfactory example of self-government, it is highly desirable that it be kept distinct from any plan or method of governmental regulation or control. It will be successful according to the degree to which manufacturers, distributors, and purchasers adhere to its terms and conditions.

2. The industry's responsibility.-The department cooperates only on the request of the industry and assumes no responsibility for industrial acceptance or adherence. This program was developed by the industry on its own initiative. Its success depends wholly on the active cooperation of those concerned.

3. The acceptor's responsibility.-You are entering into an entirely voluntary arrangement, whereby the members of the industry - the distributors and consumers of the product, and others concerned-hope to secure the benefits inherent in commercial standardization. Those responsible for this standard realize that instances may occur in which it will be necessary to supply or purchase items not included therein. The purpose is, however, to secure wider support for nationally recognized standards covering grade, quality, and other characteristics of products. Consumers can make the program a success if, in their purchasing, they will make a definite and conscientious effort to specifiy in terms of this commercial standard.

4. The department's responsibility.-The function performed by the Department of Commerce is fourfold: First, to act as a referee to insure adequate consideration of the needs of all interests; second, to supply such assistance and advice in the development of this program as past experience with similar programs may suggest; third, to solicit and record the extent of adoption and adherence to the standard; and, fourth, to add all possible prestige to this standardization movement by publication and promulgation if and when it is adopted and accepted by all elements directly concerned. 


\title{
REQUEST FOR COMMERCIAL STANDARDS
}

\author{
Date
}

\section{Division of Trade Standards,} Bureau of Standards,

$$
\text { Washington, D. C. }
$$

Gentlemen: The undersigned wishes to examine the commercial standards checked on the reverse side of this page, with a view toward accepting them as our standard of practice in the production, distribution, or consumption of the standardized lines.

Signed .

Title

Company

Street address

City and State 


\section{COMMERCIAL STANDARDS}

Item
CS. No.
1-28. Clinical thermometers.
2-29. Surgical gauze (preparation postponed).
3-28. Stoddard solvent.
4-29. Staple porcelain (all-clay) plumbing fixtures.
5-29. Steel pipe nipples.
6-29. Wrought-iron pipe nipples.
7-29. Standard weight malleable iron or steel
s-30. Plain and thread plug and ring gage blanks
(in preparation).
9-29. Builders'template hardware.
10-29. Brass pipe nipples.
11-29. Regain of mercerized cotton yarns.

CS. No.

Item

13-30. Dress patterns.

14-29. Boys' blouses, waists, shirts, and junior shirts (in preparation)

15-29. Men's pajamas (made from woven fabrics). 16-29. Wall paper.

17-30. Diamond core drill fittings.

18-29. Hickory golf shafts.

19-30. Foundry patterns of wood

20-30. Staple vitreous china plumbing fixtures.

21- Interchangeable ground glass joints (in

preparation)

22- Builders' hardware (nontemplate) (in preparation).

12 